\title{
The Relationship between the Mite, Eriophyes vitis (Pagst.) and Leaf Curl on Vitis vinifera L. cv. Shiraz
}

\author{
A. SCHWARTZ \& C. A. DE KLERK \\ Viticultural and Oenological Research Institute, Private Bag X5026, Stellenbosch 7600, Republic of South Africa.
}

Submittted for publication: July 1984

Accepted for publication: August 1984

\begin{abstract}
Eriophyes vitis (Pagst.) is known as the grape erineum or blister mite. The distribution of the erineum mite is world wide, being a pest of grapevines in nearly every vine growing country. Three physiologically distinct strains of the mite are reported, each characterised by the type of injury produced: the bud strain (which causes stunted growth), the erineum or blister strain (blisters with abnormal hairs) and the leaf-curling strain (distinct leaf curl) (Jeppson, Keifer \& Baker, 1975).
\end{abstract}

The leaf erineum was first described in Germany in the mid-nineteenth century (Avidov \& Harpaz, 1969), while the bud mite strain was first identified in California in 1938 and as the name implies, is only to be found in the buds (Avidov \& Harpaz, 1969). The leaf curl strain was first discovered in California in 1945 and it is stated that this strain produces distinct leaf curl, few abnormal plant hairs, but no typical erinose areas or galls (Smith \& Stafford, 1948; Jeppson et al., 1975). The only reference to leaf curl in South Africa is that by Whitehead et al., (1978). According to these workers the abnormality occurs under shaded or cool conditions, which often occur in autumn in overgrown vineyards, or in nurseries or in lath houses. According to the available literature, although E. vitis had been implicated, no attempt had been made to prove its association with leaf curl.

During January 1983 abnormal leaf growth was reported in a young Shiraz vineyard, not yet trellised, in the Ashton district, Western Cape, Republic of South Africa. Examination of the affected plants revealed that both erineum and leaf curl symptoms were present. Further observations were carried out to determine whether $E$. vitis is involved as the cause of leaf curl.

\section{PROCEDURE}

A randomised block experiment consisting of two treatments with six replications was laid out in the $V$. vinifera $\mathrm{cv}$. Shiraz vineyard. Each plot contained five vines in the row and these were separated from adjacent plots by two non-data plants.

Two shoots on each of five vines (60 per treatment) were chosen and the incidence of erineum leaves and those with leaf curl noted. The terminals of these shoots were marked and the new growth, subsequent to an acaricide treatment, evaluated for the presence of leaf curl and erineum.

In order to test for significance between the two treatments the percentage shoots with leaf curl was subjected to Friedman's analysis of variance (non-parametric). In addition, prior to the spray treatment, ten leaves per vine, for a total of 300 per treatment were sampled to determine the mite infestation. The presence of one or more mites per leaf was the criterion for infested leaves.

Six plots were sprayed during véraison (February) with chlorobenzilate 50 emulsifiable concentrate at $50 \mathrm{ml} / 100 l$ water by means of a high volume spray pump. The remaining six plots were kept unsprayed as a control.

\section{RESULTS}

The most important findings were the following:

1. A mean of $97 \%$ of the sampled leaves were infested with $E$. vitis before spraying.

2. Generally, the erineum occurred on the older (mature) leaves, whilst the leaf curl symptoms were more evident on the young leaves. In the latter case the edges of these leaves curl downwards and inwards; some of the leaves were damaged to the extent of being grotesque.

3. Erineum leaves and curled leaves occurred in a ratio of 1 to 12 on the same shoot (data not shown).

4. A small number of leaves (less than $1 \%$ ) exhibited both the above mentioned symptoms.

5. E. vitis was restricted to the ventral surface of leaves exhibiting leaf curl symptoms. The mites were found to frequent the niche formed by the mid- and secondary veins and the leaf surface where the rounding of the vein provide some protection. Small numbers of mites were also observed moving over the ventral surface of affected leaves.

6. Five weeks following the application of the acaricide the examination of new shoot growth revealed a $2 \%$ incidence of leaf curl in the sprayed plots against $54 \%$ for the unsprayed control plots (Table 1). The treatment difference was significant (at $\mathrm{P}=0,05, \mathrm{LSD}$ $=4,80)$.

7. Erineum was absent on the new shoot growth.

S. Afr. J. Enol. Vitic., Vol. 5. No. 21984 
TABLE 1

Post-treatment evaluation of new growth for the presence of leaf curl symptoms

\begin{tabular}{|c|c|c|c|c|c|c|}
\hline \multicolumn{4}{|c|}{ Sprayed* } & \multicolumn{3}{|c|}{ Unsprayed control } \\
\hline Replicate & \multicolumn{2}{|c|}{ No of terminals - } & $\%$ & \multicolumn{2}{|c|}{ No of terminals - } & $\%$ \\
\hline I & 0 & 8 & 0 & 6 & 10 & 60 \\
\hline II & 0 & 8 & 0 & 4 & 9 & 44 \\
\hline III & 1 & 7 & 14 & 4 & 8 & 50 \\
\hline IV & 0 & 8 & 0 & 3 & 6 & 50 \\
\hline V & 0 & 6 & 0 & 5 & 9 & 56 \\
\hline VI & 0 & 8 & 0 & 5 & 8 & 63 \\
\hline Total & 1 & 45 & 0 & 27 & 50 & \\
\hline Mean & & & 2,2 & & & 54,0 \\
\hline
\end{tabular}

* Treatment : chlorobenzilate 50 emulsifiable concentrate

\section{CONCLUSIONS}

The results of this experiment show that the responsible agent for the specific leaf curl investigated here is the mite $E$. vitis which, moreover, is controlled by the same treatment generally recommended for erineum.

In the past the presence of leaf curl in vineyards has generally been referred to as leaf roll virus, for which no field treatment exists. In the light of the present knowledge any such symptom development should be investigated as it has been demonstrated that a chemical remedy for the ailment is possible where the leaf curl mite is involved.

\section{REFERENCES}

AVIDOV, Z. \& HARPAZ, I., 1969. Plant pests of Israel. Israel University Press, Jerusalem.

JEPPSON, L. R., KEIFER, H. H. \& BAKER, E. W., 1975. Mites injurious to economic plants. University of California Press, Los Angeles.

SMITH, M. \& STAFFORD, E. M., 1948. The bud mite and the erineum mite of grapes. Hilgardia 18, 319-334.

WHITEHEAD, V. B., RUST, D. J., PRINGLE, K. A. \& ALBERTSE, G., 1978. The bud infesting strain of the grape leaf blister mite, Eriophyes vitis (Pagst.), on vine in the Western Cape Province. J. ent. Soc. Sth. Afr. 41 (1), 9-15. 